\title{
A study on adulteration of alcoholic beverages in Poland. What next?
}

Studia nad fałszowaniem napojów alkoholowych w Polsce. Co dalej?

\section{Introduction}

Food adulteration is the actions taken to interfere with, add to or adjust a food item and in so doing making the food or drink of lower quality or fraudulent (Spink \& Moyer, 2011; Manning \& Soon, 2014). Economically motivated adulteration (EMA), a sub-category of food fraud, is deception for economic gain including activities such as substitution, particularly with substandard or inferior products, unapproved additions or enhancements, misbranding or misrepresentation, tampering, counterfeiting, using stolen goods and others (Spink \& Moyer, 2011; Manning \& Soon, 2014; Kowalska, Soon \& Manning, 2018). Article 3 of the Polish Act on Safety of Food and Nutrition (2006) states that an adulterated foodstuff is one where the composition or other properties are changed without informing the consumer about it, or a foodstuff is altered in order to conceal its intrinsic composition or other properties and affecting the safety of the foodstuff. Further, under Article 3 of the Act on Commercial Quality of Agricultural and Food Products (2000), which deals with quality issues and their economic implications for consumers, an adulterated agricultural and food product is defined as:

a product whose composition does not comply with the provisions of regulations regarding commercial quality of individual agri-food items, or a product changed (including mislabelling) in order to conceal its intrinsic composition or other pro- 
perties, as long as the aforementioned non-compliances or changes significantly adversely affect consumer interests.

Both regulatory definitions focus on mislabelling, particularly product composition, in preference to intentional acts of adulteration. This is not in step with other definitions found in global standards and regulations, where intent is seen as an inherent aspect of the determination of an instance of food fraud including adulteration (Kowalska et al., 2018). In Poland, liability rests with the food business operator who places the adulterated agri-food item on the market, and the only condition needed for the regulator to impose a sanction is the fact that the product is placed on the market for sale (Supreme Administrative Court, 2013; Kowalska, 2016; Kowalska \& Kowalski, 2018).

Alcohol is one of the top four most often reported fraudulent food commodities after meat, seafood and milk (Bouzembrak et al., 2018; Rezazade, Summers \& Lai Teik, 2022). Adulteration of alcohol is a significant challenge if the adulterants have the potential to cause harm (Snowdon, 2012; Soon \& Manning, 2019), especially through the non-disclosed use of ethylene glycol and methanol to fortify (raise the alcohol level), and/ or improve flavour (Laher, Goldstein, Wells, Dufourq \& Moodley, 2013; Manning \& Kowalska, 2021; Neufeld, Lachenmeier, Hausler \& Rehm, 2016; Rostrup et al., 2016; Shafi, Imran, Usman, Sarwar \& Tahir, 2016). Alcohol is a major cause of disease and death globally (WHO, 2014) with alcohol consumption being the leading risk factor in disability-adjusted life-years between the ages of 15 and 49 (Gakidou et al., 2017). Most countries implement alcohol-related policy aimed at regulating consumption to safe limits. This policy can include alcohol pricing-related interventions, e.g. the introduction of a minimum price per unit of alcohol or alcohol excise duties (tax). The use of excise and/or product specific taxation may form part of the regulation of the consumption of commodities such as alcohol (Yeomans, 2019). Whilst such taxes can derive revenue to offset the health costs of excessive alcohol consumption for the state, an increase in the tax burden to individuals and businesses related to the sale of alcohol, is in itself a driver for illicit behaviour (Soon \& Manning, 2019).

Introducing illicit trade in adulterated alcohol products leads to negative economic and social consequences. Adulteration of alcohol intended for human consumption may pose a risk to public health. Alcohol adulteration threatens primarily the security of the economic interests of foodstuff purchasers, including consumers and competitors (Kowalska, 2019). The sale of adulterated agri-foods drives asymmetric or inequivalent value in use with relation to the actual cost 
of purchase (Kowalczyk, 2016). Detection and then withdrawal of adulterated products from the market generates costs for enterprises and leads to increased state budget expenditure connected, among other factors, with the necessity of running additional regulatory controls, implementing a supply chain withdrawal/ recall and initiating an investigation procedure.

Article 9.1(b) of Regulation EU 2017/625 of 15 th March 2017 on official controls and other official activities performed to ensure the application of food and feed law states that competent authorities must undertake official controls regularly on all operators. The frequency of checks must be determined on a risk basis, taking into account the potential for consumers to be misled about the quantity, properties or composition, shelf-life (durability), identity, country of origin/ provenance, or method of manufacture or production of food. Agricultural and Food Quality Inspection (IJHARS) in Poland takes both corrective and preventive actions when identifying issues that could affect consumers' safety and where product integrity may have been lost. Trade Inspection (IH) in Poland conducted inspections of agri-food products in retail and wholesale trade until July 2020 when national legislation regarding these issues was modified (The Act on Amending the Act on Commercial Quality of Agricultural and Food Products and Certain Other Acts as of January 23, 2020). Furthermore, both IJHARS and IH conducted border inspections of exported/imported agri-food products until July 2020, but now IH is not responsible for food control in Poland. These two inspection bodies have published the administrative decisions regarding adulteration of food on-line, which contributes to the effective implementation of the principle of transparency introduced in Article 9 and 10 of Regulation (EC) No 178/2002 laying down the general principles and requirements of food law. Detecting adulteration of food and making this information public, can not only involve legal consequences for businesses and individuals, but also lead to economic loss such as loss of sales, loss of contracts and so on. It is also possible, that the only consequence of detecting such violations is the imposing of financial penalties on the perpetrators. There is a number of studies that focus on methods and devices for detecting adulterants in alcoholic beverages (Abegg, Magro, van den Broek, Pratsinis \& Güntner, 2020; Lachenmeier, 2016; Power et al., 2020), as well as studies regarding health risks related to the consumption of adulterated alcoholic beverages (Lachenmeier, Neufeld \& Rehm, 2021; Newman, Qian, Tamrakar \& Zhang, 2018). However, there is a lack of published research on reported areas of non-compliance with alcoholic beverages on a country-by-country basis, which could contribute to more effective food governance. 
The aim of this study is to review and critique the incidence of adulteration of alcoholic beverages in Poland between 2009-2019, in order to provide recommendations for governance structures to reduce the likelihood of such offences occurring in the future. The paper is structured as follows: Section 1 is an introduction to set the context for the study. Section 2 outlines the methodology applied. Section 3 presents and synthesizes existing literature and considers secondary data to review the supply and demand for alcohol beverages in Poland as compared with other countries, to review and make a detailed analysis of the irregularities detected by IJHARS in adulterated alcoholic beverages in Poland between 2016-2019, and to review mislabelling of alcoholic beverages confirmed by $\mathrm{IH}$ between $2009-2019$ in retail and wholesale trade. Section 4 concludes the paper and seeks to frame the challenges of addressing the sale of adulterated and mislabelled alcoholic beverages in Poland and to provide recommendations on how governance structures can be improved.

\section{Methodology}

The methodological approach was firstly to undertake a literature review and then to consider secondary data to review the supply and demand for alcohol beverages in Poland as compared with other countries, secondly define and outline the challenge of food adulteration and then to analyse: (1) the IJHARS data on the prevalence of adulteration of alcoholic beverages in Poland; (2) the IH data on the prevalence of mislabelling of alcoholic beverages in Poland detected in retail and wholesale trade. Previous studies (Kowalczyk, 2015; Kowalska et al., 2018; Kowalska, Bieniek \& Manning, 2019) have used IJHARS food inspection data to critique the issues around food adulteration and mislabelling so this provides the rationale for this research.

Data published by IJHARS over the period 2016-2019 were used to assess alcoholic beverage adulteration in Poland. The choice of the studied period is determined by the fact that since November 2015 the disclosure of IJHARS decisions related to food adulteration detection became mandatory (Kowalska \& Kowalski, 2018). Generally, IJHARS concentrates on food production in the Polish territory, thus the analysed results of official controls relate mainly to alcoholic beverages manufactured in Poland. Over the studied period 2016-2019, there are only 41 full-texts of administrative decisions publicised on the IJHARS webpage regarding 56 adulterated alcohol beverages. For the purposes of the conducted analyses, we built a database (using a Microsoft Excel (2016) spre- 
adsheet) of confirmed adulteration of alcoholic beverages, including data on the date of the decision, trade and generic name of a product, and the reason for contesting (confirmed irregularities). Data published by IH in its annual activity reports over the period 2009-2019 were used to assess mislabelling of alcoholic beverages in Poland. With regard to the main research goal, the general research question considered in this study is:

What are the most frequently reported areas of non-compliance with alcoholic beverages in Poland?

\section{Results and analysis}

\subsection{The supply and demand for alcoholic beverages in Poland}

In 2017, there was a negative balance in foreign trade in alcohol products in Poland, but there was a positive balance recorded in trade in beer and vodka (IERiGŻ, 2018). Poland, Russia and other Eastern European countries are significant producers and consumers of vodka, which is made from ethyl alcohol of agricultural origin that has been produced via fermentation of grains, potatoes or other agricultural products (Wiśniewska, Śliwińska, Dymerski, Wardencki \& Namieśnik, 2015).

The alcohol market situation in Poland was changing for political reasons in the 1980s and 1990s, which particularly affected the illicit supply of ethyl alcohol of agricultural origin and the performance of official controls on the market. During the strikes in 1980 and 1981 in Poland, a total ban on the sale of alcohol was imposed (Smith, 1982). Over the period 1981-1989, the sale of alcohol was rationed, and the prices of alcohol beverages were high. It is worth emphasizing too that since the fall of Communism in 1989, the economic accessibility of vodka has been growing dynamically in post-communist Poland. Between 1990 and 2003, a gross monthly average wage allowed individuals to buy around 50-85 half-litre bottles of vodka per month (Moskalewicz \& Sierosławski, 2005), whereas, in 2018 the gross monthly average wage allowed individuals to buy around 187 same size bottles of vodka per month (Statistics Poland, 2019), and this has made alcohol more affordable. Moskalewicz, Razvodovsky and Wieczorek (2016) state that this economic phenomenon is driven by the transition in Poland to a market economy. This means that an initial laissez faire approach can lead to the abandoning of alcohol monopolies and destroy existing alcohol control systems. Price structures for alcohol can drive poor behaviour and low 
alcohol prices can be reinforced by the illicit supply of low cost unreported alcohol (Moskalewicz et al., 2016). Effective control of illicit supply is undermined by the large proportion of unrecorded alcohol distributed through seemingly legal networks. Moskalewicz, Razvodovsky and Wieczorek (2016) underline that over the period 1990-2011, reported alcohol consumption increased by $20 \%$ in Poland while in contrast in EU15 it decreased by 20\%. Moreover, in Poland the levels of unreported alcohol consumption were much higher in the 1990s than in the 2000s.

Gańczak et al. (2020) found out that in Poland, age-standardised disability-adjusted life years (DALYs) from alcohol use disorders increased substantially between 1990 and 2017. Moreover, alcohol use disorders ranked as the 11th leading cause of age-standardised years of life lost (YLLs) in Poland in 2017, but 20th in Central European countries as a whole (Gańczak et al. 2020). Alcohol consumption in Poland (similar to some Northern and Eastern European countries) differs from the Western European pattern, as Polish people tend to drink spirits (e.g. vodka) and beer, rather than wine, and are inclined to engage in binge drinking more frequently (Hu et al., 2016). The large burden of alcohol use disorders urgently requires both policy and health system response.

In 2018, the three top European producers of alcoholic beer were Germany, with a production of 8.3 billion litres (amounting to 21\% of the EU total production), the United Kingdom (UK) (4.5 billion litres produced, or 12\%), and by a small margin Poland (4.0 billion litres, or 10\%) (see Eurostat, 2019). In Poland, there was an average annual growth rate (AAGR) of $4.9 \%$ in the production volume of beer within the period 1995-2016 (Szajner, 2018). Polish beer producers sell most of their production in the domestic market with only $8.2 \%$ of the production volume being exported. The Polish brewery industry is characterised by high seasonality with the greatest production and consumption of beer being during the summer months (IERiGŻ, 2018). The brewing industry in Poland has much greater economic significance to the economy than the national spirits industry and wine industry. In 2017, output at basic prices by the industry amounted to EUR 1858.8 million for beer, EUR 862.2 million for spirits, and EUR 154.1 million for wine. In 2017, the number of people employed by the beer industry was twice the number of employees in spirits industry and eight times bigger than the number of employees in the Polish wine industry. Moreover, the gross return index on sales obtained in 2017 amounted to 14.1\% for beer industry, $12.0 \%$ for wine industry and $2.3 \%$ for the spirits industry and the Polish beer industry had return on equity (ROE) of $30.4 \%$ in 2017, wine industry had ROE of 13.6\%, and spirits industry had ROE of 2.9\% (IERiGŻ, 2018). 
Return on beer industry equity of 30-40\% over the period 2013-2018 makes this sector attractive for investors.

Since 2011, an interesting trend in the beer market in Poland has been the increase in the number of microbreweries and their contribution to national beer production namely: craft breweries, brewpubs, and collaboration breweries (Patterson \& Hoalst-Pullen, 2014; Wojtyra \& Grudzień, 2017). In 2018 in the United States (US), there were 7450 breweries, among these were 7346 craft breweries (Brewers Association, 2020). In Poland, the total number of breweries increased from 65 in 2010 to 238 in 2016, but the number of large/ non-craft breweries producing more than 200000 hectolitres of beer annually has remained at the same level $(n=22)$. The craft beer revolution has been influencing the beer industry at national and global scale and has had a positive impact on socio-economic development of the regions concerned, due to the associated job creation linked to the tourism sector. The quality of Polish craft beers is different to the quality of mass-produced beers in the country. There is also a regulatory driver for Polish breweries to implement effective food quality and food safety management systems. In her study, Judzińska (2017) presented the state of implementation of three mandatory systems, i.e., Good Hygiene Practice (GHP), Good Manufacturing Practice (GMP), and Hazard Analysis and Critical Control Points (HACCP), in particular sections of the Polish food industry. The study showed that $85 \%$ of breweries had implemented HACCP by 2015 whereas only $55 \%$ of meat processors had implemented the system. Over $90 \%$ of breweries in the study have applied the principles of GMP and GHP. Similar to many other food business operators, there has been little interest in going further and implementing non-mandatory food quality and safety management systems among brewers in Poland (Pietrzyck, Petersen \& Jarzębowski, 2018).

Globalisation significantly affects the changing patterns and the convergence of beer consumption (Colen \& Swinnen, 2016). In 2016, the consumption of alcohol in Poland was 11.6 litres of pure alcohol per capita (15+), which was 1.8 litres more than the average for the WHO European Region. The share of beer in terms of total pure alcohol consumption in Poland (traditionally a spirit drinking country) was $27.7 \%$ in 1965 , and $55.1 \%$ in 2009 . In traditionally beer drinking countries such as the UK and Ireland, this share fell from $81.0 \%$ to $36.3 \%$, and from $74.9 \%$ to $51.1 \%$ respectively, and in other traditionally spirit drinking countries the beer share also increased from $1.5 \%$ to $31.4 \%$ in China and from $14.6 \%$ to $37.3 \%$ in Russia (Colen \& Swinnen, 2016). The influence of alcohol policy in Poland including availability, marketing and pricing of beer is worthy of note. There is no control of the marketing of beer in Poland on 
the Internet or social media, no ban on below-cost promotion or sponsorship of sports events and youth events, and this exceptional position may have an impact on beer consumption and alcohol-related health issues.

Wine-growing does not represent an integral part of the life and culture of Poland, but viticulture and wine making have been growing rapidly over the past decade. Over the period 2008-2018, the areas planted with vines increased more than tenfold and the number of wine producers increased more than sixfold (IERiGŻ, 2018). Global warming and obtaining new grape varieties (resistant to frost) are two main factors affecting the development of the sector in Poland (Olewnicki, 2018). Maciejczak (2017) states that

although viticulture cultivation in Poland is today of little economic significance, and will remain as such in the short and probably medium term perspective, in the long run, driven by climate changes associated with technological and socio-economic transformations, it might become a significant branch of the agri-business sector (p. 156).

Thus, the alcohol market in Poland is transitioning to a new normal, and this makes analysis of the potential for fraud of particular interest.

\subsection{Analysis of the results of official controls on the alcohol market in Poland}

Over the period 2016-2019, IJHARS in Poland disclosed 71 administrative decisions concerning adulterated alcoholic beverages. These comprised $5.3 \%$ of the decisions concerning all product categories $(n=1347)$ made by IJHARS in this timeframe. This is comparable with what is observed across the EU as the EU Food Fraud Network and the Administrative Assistance and Cooperation System shows that non-compliant cases regarding alcoholic beverages $(n=14)$ and wine $(\mathrm{n}=6)$ comprised only $2.7 \%$ of all the Administrative Assistance and Food Fraud cases ( $\mathrm{n}=1014$ ) between 2016 and 2017 (EC, 2016; Unpublished DG SANTE data, 2018).

Analysis of full-texts of IJHARS decisions on adulterated alcohol beverages for the time period 2016-2019 (Table 1) showed that non-compliance occurred in the following product categories: beer $(n=27)$, wine $(n=13)$; fruit vodka $(n=7)$; mead $(\mathrm{n}=5)$; aromatised wine-based drink $(\mathrm{n}=3)$, and vodka $(\mathrm{n}=1)$. Two categories, 'composition' and 'misnomer', were divided into subcategories for more detailed analysis. Moreover, there were commonly multiple non-conformances 
relating to one specific alcohol beverage so the numbers presented in Table 1 exceed 100\%. The analysis of the IJHARS data for the period 2016-2019 showed that inaccurate composition declarations were the main irregularity associated with alcoholic beverages in Poland. The most common specific violations were: - Lower actual alcoholic strength of the product than the value declared;

- Items being present that were not included on the ingredients list; and

- Misnomer (incorrect or incomplete name of the product).

These results from the IJHARS data give the answer to the main research question in this study. The type of non-compliance varies according to the specific nature of the product and the vulnerabilities to EMA resulting from the potential economic benefit to the perpetrator of misleading consumers and the level of controls at the stage of the supply chain at which the intervention could take place (Galvin-King, Haughey \& Elliott, 2018; Kowalska, 2019; van Ruth, Luning, Silvis, Yang \& Huisman, 2018; Yang et al., 2019; Yan, Erasmus, Toro, Huang \& van Ruth, 2020).

Table 1. Irregularities in adulterated alcoholic beverages detected by IJHARS in 2016-2019

\begin{tabular}{|c|c|c|c|c|c|c|c|c|}
\hline $\begin{array}{c}\text { ALCOHOLIC BEVER- } \\
\text { AGES } \\
\text { (Cases: } \mathrm{n}=56) \\
\text { Type of irregularity }\end{array}$ & Beer & Wine & $\begin{array}{c}\text { Fruit } \\
\text { vodka }\end{array}$ & Mead & $\begin{array}{c}\text { Aromatised } \\
\text { wine-based } \\
\text { drink }\end{array}$ & Vodka & $\begin{array}{l}\text { No of } \\
\text { cases }\end{array}$ & (\%) \\
\hline $\begin{array}{l}\text { Composition incl. mis- } \\
\text { labelling (mainly beer) }\end{array}$ & $\checkmark$ & $\checkmark$ & & $\checkmark$ & & & 21 & 37.5 \\
\hline $\begin{array}{l}\text { Missing items in the } \\
\text { ingredients list }\end{array}$ & $\checkmark$ & $\checkmark$ & & & & & 18 & 32.1 \\
\hline $\begin{array}{l}\text { Misleading information } \\
\text { on the variety of hop } \\
\text { used }\end{array}$ & $\checkmark$ & & & & & & 5 & 8.9 \\
\hline $\begin{array}{l}\text { Declaration of ingre- } \\
\text { dients not used in the } \\
\text { production process }\end{array}$ & $\checkmark$ & & & & & & 8 & 14.3 \\
\hline $\begin{array}{l}\text { Lower content of extract } \\
\text { from hopped wort than } \\
\text { the value declared }\end{array}$ & $\checkmark$ & & & & & & 4 & 7.1 \\
\hline $\begin{array}{l}\text { Misleading information } \\
\text { on the total/volatile acidi- } \\
\text { ty of the alcoholic drink }\end{array}$ & & & & $\checkmark$ & & & 3 & 5.4 \\
\hline $\begin{array}{l}\text { Misleading information } \\
\text { on the ash content }\end{array}$ & & & & $\checkmark$ & & & 2 & 3.6 \\
\hline $\begin{array}{l}\text { No reference to allergens } \\
\text { (sulphites, barley malt, } \\
\text { wheat malt) }\end{array}$ & $\checkmark$ & $\checkmark$ & & & & & 2 & 3.6 \\
\hline
\end{tabular}




\begin{tabular}{|c|c|c|c|c|c|c|c|c|}
\hline $\begin{array}{l}\text { Misleading information } \\
\text { on content percentage of } \\
\text { an ingredient }\end{array}$ & $\checkmark$ & & & & & & 2 & 3.6 \\
\hline $\begin{array}{l}\text { Misleading information } \\
\text { on the use preservatives } \\
\text { (without preservatives) }\end{array}$ & & & & $\checkmark$ & & & 1 & 1.8 \\
\hline $\begin{array}{l}\text { Misleading information } \\
\text { on raw material used in } \\
\text { the production process }\end{array}$ & & & $\checkmark$ & & & & 2 & 3.6 \\
\hline $\begin{array}{l}\text { Lower alcoholic } \\
\text { strength of the product } \\
\text { than the value declared }\end{array}$ & $\checkmark$ & $\checkmark$ & $\checkmark$ & $\checkmark$ & $\checkmark$ & $\checkmark$ & 18 & 32.1 \\
\hline $\begin{array}{l}\text { Misnomer (mainly } \\
\text { wine) }\end{array}$ & $\checkmark$ & $\checkmark$ & $\checkmark$ & & & & 13 & 23.2 \\
\hline $\begin{array}{l}\text { Misleading information } \\
\text { on the type of sparkling } \\
\text { wine (champagne - the } \\
\text { name of the protected } \\
\text { designation of origin) }\end{array}$ & & $\checkmark$ & & & & & 2 & 3.6 \\
\hline $\begin{array}{l}\text { Misleading information } \\
\text { on the type (sweetness) } \\
\text { of wine }\end{array}$ & & $\checkmark$ & & & & & 2 & 3.6 \\
\hline $\begin{array}{l}\text { Incomplete name of the } \\
\text { product (e.g. a lack of the } \\
\text { wording "spirit drink") }\end{array}$ & & & $\checkmark$ & & & & 3 & 5.4 \\
\hline Place of origin & $\checkmark$ & $\checkmark$ & $\checkmark$ & & & & 8 & 14.3 \\
\hline Falsification of shelf life & $\checkmark$ & & & & & & 5 & 8.9 \\
\hline $\begin{array}{l}\text { Misleading graphics on } \\
\text { the label (grape) }\end{array}$ & & $\checkmark$ & & & & & 2 & 3.6 \\
\hline $\begin{array}{l}\text { Higher alcoholic } \\
\text { strength of the product } \\
\text { than the value declared }\end{array}$ & $\checkmark$ & & & & & & 1 & 1.8 \\
\hline
\end{tabular}

Source: own elaboration based on the IJHARS administrative decisions regarding detected food adulteration published on https://www.gov.pl/web/ijhars/rejestry.

Since Poland is one of the top three producers of beer in the EU, these results are of interest. All of the adulterated beers $(n=27)$ were mislabelled and consumers were most often misled about the actual composition of the product (Table 2). Specifically, irregularities included: misleading information on the variety of hop used and lower content of extract from hopped wort than the value declared. Laboratory tests indicated 'lower alcoholic strength of the product than the value declared' for $18.5 \%$ of the products, which prejudiced the economic interests of beer purchasers too.

Poland is a significant producer and consumer of vodka. In cases of mislabelled fruit vodka products indicated by IJHARS ( $n=7$ ), again, the actual alcoholic 
strength by volume being lower than that appearing on the label $(n=6)$, and incomplete name of the product $(n=3)$ were key problems.

Table 2. Irregularities in adulterated beer detected by IJHARS in 2016-2019

\begin{tabular}{|l|r|r|}
\hline \multicolumn{2}{|c|}{ BEER (cases: $\mathbf{n}=27)$} \\
\hline \multicolumn{1}{|c|}{ Type of irregularity } & No of cases & $\begin{array}{c}\text { Proportion of the beer } \\
\text { cases (\%) }\end{array}$ \\
\hline Composition incl. mislabelling & 18 & 66.7 \\
\hline \multicolumn{1}{|c|}{ Missing items in the ingredients list } & 15 & 55.6 \\
\hline $\begin{array}{l}\text { Misleading information on the variety of hop } \\
\text { used }\end{array}$ & 5 & 18.5 \\
\hline $\begin{array}{l}\text { Declaration of ingredients not used in the } \\
\text { production process }\end{array}$ & 8 & 29.6 \\
\hline $\begin{array}{l}\text { Lower content of extract from hopped wort } \\
\text { than the value declared }\end{array}$ & 4 & 14.8 \\
\hline $\begin{array}{l}\text { Misleading information on content percetage } \\
\text { of an ingredient }\end{array}$ & 4 & 14.8 \\
\hline $\begin{array}{l}\text { No reference to allergens (barley malt, wheat } \\
\text { malt) }\end{array}$ & 1 & 3.7 \\
\hline $\begin{array}{l}\text { Lower alcoholic strength of the product } \\
\text { than the value declared }\end{array}$ & 5 & 18.5 \\
\hline Place of origin & 4 & 14.8 \\
\hline Falsification of shelf life & 5 & 18.5 \\
\hline Misnomer & 5 & 18.5 \\
\hline $\begin{array}{l}\text { Higher alcoholic strength of the product } \\
\text { than the value declared }\end{array}$ & 1 & 3.7 \\
\hline
\end{tabular}

Source: own elaboration based on the IJHARS administrative decisions regarding detected food adulteration published on https://www.gov.pl/web/ijhars/rejestry.

Between 2009 and 2019, IH in Poland assessed the commercial quality of most of the food products categories in retail and wholesale trade, focusing on the provision of food information to consumers. The IH annual activity reports were published regularly. The regulatory checks on food labelling undertaken showed a decline over time (Table 3) from 76040 checks in 2009 to 28458 in 2019. Compound annual growth rate (CAGR) of the number of checks undertaken by IH in the food trade within the studied period 2009-2019 shows a decrease per annum of $8.55 \%$. This reflects the lower budgetary provision for the state food control in the retail and wholesale trade in Poland (Office of Competition and Consumer Protection [UOKiK], 2009; 2010; 2011; 2012; 2013; 2014; 2015; $2016 ; 2017 ; 2018 ; 2019)$. It is worrying that the number of checks of alcoholic 
beverages undertaken by IH went down from 4560 in 2009 to 162 in 2018 and only 12 in 2019 (Table 3).

Table 3. No of batches of food products and specifically alcoholic beverages checked by IH in food stores and wholesale outlets in Poland between 2009 and 2019

\begin{tabular}{|c|c|c|}
\hline Year & $\begin{array}{c}\text { Number of batches of food } \\
\text { products tested }\end{array}$ & $\begin{array}{c}\text { Number of batches of } \\
\text { alcoholic beverages tested }\end{array}$ \\
\hline 2009 & 76040 & 4560 \\
\hline 2010 & 63559 & 3678 \\
\hline 2011 & 58438 & 1086 \\
\hline 2012 & 60996 & 1213 \\
\hline 2013 & 57525 & No data \\
\hline 2014 & 53606 & 836 \\
\hline 2015 & 52790 & 1182 \\
\hline 2016 & 39191 & 1980 \\
\hline 2017 & 35128 & 684 \\
\hline 2018 & 29071 & 162 \\
\hline 2019 & 28458 & 12 \\
\hline
\end{tabular}

Source: UOKiK (2009; 2010; 2011; 2012; 2013; 2014; 2105; 2016; 2017; 2018; 2019).

Figure 1. Proportion of mislabelled batches of products checked by IH in Poland between 2009 and 2019

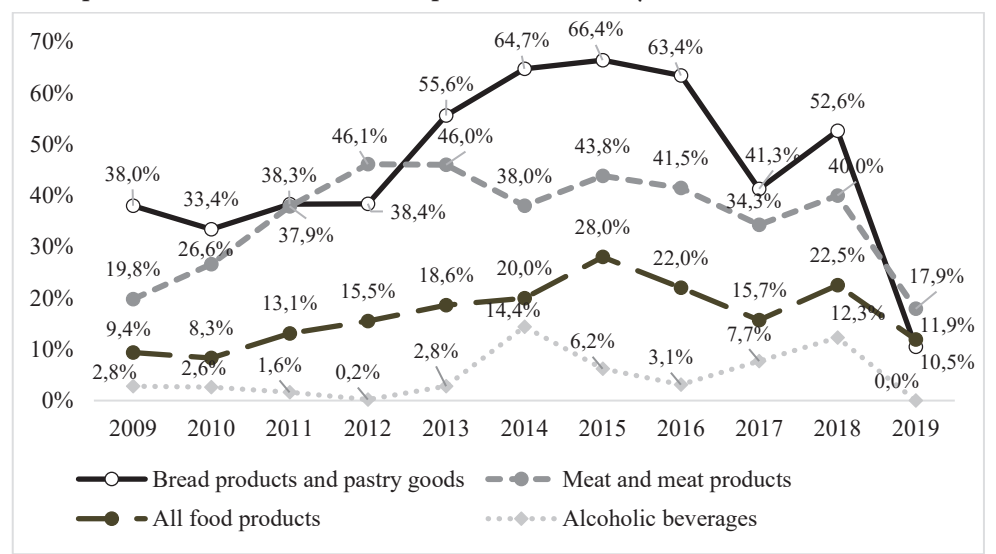

Source: UOKiK (2009; 2010; 2011; 2012; 2013; 2014; 2105; 2016; 2017; 2018; 2019).

Analysis of the IH Reports shows that alcoholic beverages are less commonly mislabelled than other product categories (Figure 1) but are still mislabelled. However, 'bread products and pastry goods' and 'meat and meat products' are two categories where mislabelling is relatively more frequent, particularly when products are sold unpackaged (Kowalska, Soon \& Manning, 2018; Kowalska, 2019). Thus, whilst alcoholic products are not determined as the most 
frequently tested products that are shown to be adulterated, such results as contained in this paper are still of concern.

\section{Conclusion}

Since Poland is a significant producer and consumer of vodka and beer in Europe and throughout the world, the potential for adulteration (especially mislabelling) creates a vulnerability in this market. Analysis of both IJHARS and IH data showed that alcoholic beverages have shown lower levels of non-conformance in regulatory testing than other sectors such as bakery and cereal or meat industry, but any loss of trust could damage the burgeoning alcoholic beverage sector in Poland. Inaccurate composition declarations are the major area of non-compliance with alcoholic beverages in Poland. Where non-compliances were detected, instances of lower actual alcoholic strength of the product than the value declared, missing items in the list of ingredients, or incorrect or incomplete name of the product were of concern. Whilst human error may have played a role in these incidents, multiple labelling errors occurring with one specific product shows system failure at the business. The reducing frequency of regulatory control sampling may also be a driver of intentional misleading of the consumer as the level of deterrence is reduced. Regulation EU 2017/625 calls for reducing the dependency of the official control system on public finances i.e. that regulatory controls should be risk based and the onus is on businesses to self-regulate. Competent authorities should collect fees or charges to cover the costs they incur when performing official controls on certain operators and for certain activities, and to compensate for the costs of official controls performed in view of issuing an official certificate or attestation and/or undertaking controls at border points. However, reduced surveillance in the absence of effective self-regulation creates a potential EMA vulnerability for the sector and for consumers themselves. Both IJHARS and IH data were restricted to the control activities from which they result. Data collection methods used are of particular importance here. Furthermore, the frequency of official control sampling varied significantly during the period studied and was relatively low in some years, and it was a limitation in this research.

The degree of implementation of GHP, GMP, and HACCP systems in Polish breweries is satisfactory. However, the systems designed to prevent intentional adulteration of food and help to demonstrate product authenticity such as Threat Assessment and Critical Control Points (TACCP), Vulnerability Assessment and 
Critical Control Points (VACCP) or Hazard Analysis and Risk-Based Preventive Controls (HARPC) are hardly known in Poland (Wiśniewska, 2016; Kowalska, 2017). This is a situation that needs to be addressed if effective mitigation of adulteration and product mislabelling is to occur. The Polish alcoholic beverage sector relies on product and supply chain integrity to drive consumer trust in these products both on a national and international scale. As the sector grows such formal systems will underpin its future development and success. However, they will not be the keys to success. Despite the evolution of food quality and safety schemes constituting private approaches to product compliance, the food fraud situation is not improving. The reason for this might be a strong dependence of food business operators on external motivation to deliver compliance. This is in line with the concept of Food Safety 1.0. The need is to move towards Food Safety 2.0 and ensure the purpose and motivation to develop effective systems to manage food safety, food quality and food fraud come from within, with the knowledge that all food industry workers assume their share of the responsibility to make sure that people do not consume unsafe and/or adulterated food (Soares, 2020). Creating attitudes, values and beliefs contributing to food safety culture has become critical for ensuring food integrity in today's world (see also Wiśniewska, 2018). This is confirmed by the fact that food safety culture concept became a general principle of food hygiene pursuant to a decision of the Codex Alimentarius Commission made in 2020 (FAO, WHO, 2020). Consequently, general requirements on food safety culture were included in Annex II to Regulation (EC) No 852/2004 on the hygiene of foodstuffs in accordance with the provisions of Commission Regulation (EU) 2021/382. The next step in the process of preventing adulteration of alcoholic beverages in Poland is to build a strong food safety/food fraud mitigation culture in legitimate enterprises operating in this industry. This means identifying and disseminating methods and tools to assist stakeholders to monitor and measure food safety culture in businesses operating in various sectors of the alcohol supply chain, to reduce vulnerability to illicit behaviour. The development of these tools could be the focus of further studies. 


\section{Bibliography}

\section{Normative Acts}

Commission Regulation (EU) 2017/625 of the European Parliament and the Council of 15 March 2017 on official controls and other official activities performed to ensure the application of food and feed law, rules on animal health and welfare, plant health and plant protection products, OJ EU $2017 \mathrm{~L}$ 95/1, 7.4.2017. Retrieved from http:// eur-lex.europa.eu/legal-content/EN/TXT/?uri=CELEX\%3A32017R0625(5.05.2019).

Commission Regulation (EU) 2021/382 of 3 March 2021 amending the Annexes to Regulation (EC) No 852/2004 of the European Parliament and of the Council on the hygiene of foodstuffs as regards food allergen management, redistribution of food and food safety culture, OJ EU 2021 L 74/3, 4.3.2021. Retrieved from https://eur-lex.europa. eu/legal-content/EN/TXT/PDF/?uri=CELEX:32021R0382\&from=EN (7.10.2020).

Regulation (EC) No 178/2002 of the European Parliament and of the Council of 28 January 2002 laying down the general principles and requirements of food law, establishing the European Food Safety Authority and laying down procedures in matters of food safety, OJ EC 2002 L 31/1, 1.2.2002. Retrieved from https:// eur-lex.europa.eu/legal-content/EN/TXT/PDF/?uri=CELEX:32002R0178\&fro $\mathrm{m}=\mathrm{EN}(20.02 .2020)$.

Regulation (EC) No 852/2004 of the European Parliament and of the Council of 29 April 2004 on the hygiene of foodstuffs, OJ L 139, 30.4.2004, p. 1. Retrieved from https://eur-lex.europa.eu/legal-content/EN/TXT/PDF/?uri=CELEX:02004R0852-20210324\&from=EN (7.10.2021).

The Act on Amending the Act on Commercial Quality of Agricultural and Food Products and Certain Other Acts as of January 23, 2020 (Journal of Laws of the Republic of Poland, 2020, item 285). [Ustawa z dnia 23 stycznia 2020 r. o zmianie ustawy o jakości handlowej artykułów rolno-spożywczych oraz niektórych innych ustaw (Dz. U. z 2020 r. poz. 285)].

The Act on Commercial Quality of Agricultural and Food Products as of December 21, 2000 (Journal of Laws of the Republic of Poland, 2000, No 5, item 44, as amended). [Ustawa $z$ dnia 21 grudnia 2000 r. o jakości handlowej artykułów rolno-spożywczych (Dz. U. z 2001 r. Nr 5, poz. 44 z późn. zm.)].

The Act on the Safety of Food and Nutrition as of August 25, 2006 (Journal of Laws of the Republic of Poland, 2006, No 171, item 1225, as amended). [Ustawa $\mathrm{z}$ dnia 25 sierpnia 2006 r. o bezpieczeństwie żywności i żywienia (Dz. U. z 2006 r. Nr 171, poz. 1225 z późn. zm.)]. 


\section{Judical decisions}

Supreme Administrative Court. (2013). The Judgment of 6 February 2013 in Case the liability for placing adulterated butter on the market [Wyrok NSA z dnia 6 lutego 2013 r. w sprawie odpowiedzialności za wprowadzanie do obrotu zafałszowanego masła], II GSK 2171/11.

\section{Literature}

Abegg, S., Magro, L., van den Broek, J., Pratsinis, S.E., \& Güntner, A.T. (2020). A pocket-sized device enables detection of methanol adulteration in alcoholic beverages. Nature Food, 1, 351-354. doi:10.1038/s43016-020-0095-9

Agricultural and Food Quality Inspection (IJHARS). (n.d.). Co robimy [What we do]. Retrieved from https://www.gov.pl/web/ijhars/rejestry (15.07.2021).

Bouzembrak, Y., Steen, B., Neslo, R., Linge, J., Mojtahed, V., \& Marvin, H.J.P. (2018). Development of food fraud media monitoring system based on text mining. Food Control, 93, 283-296. doi: 10.1016/j.foodcont.2018.06.003

Brewers Association. (2020). National Beer Sales \& Production Data. Retrieved from https://www.brewersassociation.org/statistics-and-data/national-beer-stats/ (23.02.2020).

Colen, L., \& Swinnen, J. (2016). Economic Growth, Globalisation and Beer Consumption. Journal of Agricultural Economics, 67(1), 186-207. doi: 10.1111/1477-9552.12128 European Commission (EC). (2016). The EU food fraud network and the system for Administrative Assistance \& Food Fraud. Annual Report 2016. Retrieved from https://ec.europa.eu/food/sites/food/files/safety/docs/food-fraud_network_activity_report_2016.pdf (4.12.2019).

European Union (EU). (2018). Report on the EU customs enforcement of intellectual property rights: Results at the EU border, 2017. Luxembourg: Publications Office of the European Union. Retrieved from https://ec.europa.eu/taxation_customs/ sites/taxation/files/report_on_eu_customs_enforcement_of_ipr_2017_en.pdf (21.05.2019).

Eurostat. (2019). Happy International Beer Day. Retrieved from https://ec.europa.eu/ eurostat/web/products-eurostat-news/-/EDN-20190802-1 (10.01.2020).

Food and Agriculture Organization of the United Nations, World Health Organization (FAO, WHO). (2020). Codex Alimentarius. General Principles of Food Hygiene CXC - 11969. Retrieved from http://www.fao.org/fao-who-codexalimentarius/sh-proxy/en/?lnk=1\&url=https\%253A\%252F\%252Fworkspace.fao.org\%252Fsites\%2 52Fcodex\%252FStandards\%252FCXC\%2B1-1969\%252FCXC_001e.pdf (7.10.2020).

Gakidou, E., Afshin, A., Abajobir, A.A., Abate, K.H., Abbafati, C., Abbas, K.M., ... Murray, C.J. L. (2017). Global, regional, and national comparative risk assessment of 
84 behavioural, environmental and occupational, and metabolic risks or clusters of risks, 1990-2016: a systematic analysis for the Global Burden of Disease Study 2016. Lancet, 390(10100), 1345-1422. doi: 10.1016/S0140-6736(17)32366-8

Galvin-King, P., Haughey, S.A., \& Elliott, C.T. (2018). Herb and spice fraud; the drivers, challenges and detection. Food Control, 88, 85-97. doi: 10.1016/j.foodcont.2017.12.031

Gańczak, M., Miazgowski, T., Kożybska, M., Kotwas, A., Korzeń, M., Rudnicki, B., ... Kopec, J.A. (2020). Changes in disease burden in Poland between 1990-2017 in comparison with other Central European countries: A systematic analysis for the Global Burden of Disease Study 2017. PloS one, 15(3), e0226766. doi: 10.1371/journal.pone.0226766

Hu, J., Pikhart, H., Kubinova, R., Malyutina, S., Pajak, A., Besala, A., ...Bobak, M. (2016). Alcohol Consumption and Longitudinal Trajectories of Physical Functioning in Central and Eastern Europe: A 10-Year Follow-up of HAPIEE Study. The Journals of Gerontology: Series A, 71(8), 1063-1068. doi: 10.1093/gerona/glv233

Institute of Agricultural and Food Economics (IERiGŻ). (2018). Rynek wyrobów alkoholowych. Stan i perspektywy [The market of alcohol products. The current state and future prospects]. Retrieved from https://www.ierigz.waw.pl/publikacje/ analizy-rynkowe/rynek-wyrobow-alkoholowych (2.01.2020).

Judzińska, A. (2017). Systemy zarządzania jakością i bezpieczeństwem żywności oraz stan ich wdrożenia w polskim przemyśle spożywczym [Food safety and quality management systems and their implementation in the Polish food industry]. Annals of the Polish Association of Agricultural and Agribusiness Economists, 19(2), 102-107. doi: 10.5604/01.3001.0010.1167

Kowalczyk, S. (2015). Authenticity of food products in the Polish market checked during 2005-2012. Roczniki Państwowego Zakładu Higieny, 66(1), 27-34.

Kowalska, A. (2016). Problem fałszowania żywności w Polsce [Food adulteration issue in Poland]. Problemy Jakości, 48(9), 28-35. doi: 10.15199/47.2016.9.4

Kowalska, A. (2017). Problematyka oszustw żywnościowych w przepisach prawa i standardach branżowych [An issue of food fraud in regulatory activities and industry standards]. Kwartalnik Nauk o Przedsiębiorstwie, 45(4), 30-41. doi: 10.5604/01.3001.0010.7451

Kowalska, A. (2019). Ekonomiczne problemy fałszowania żywności. Instrumenty przeciwdziałania [Economic problems of food adulteration. Prevention measures]. Lublin: Wydawnictwo UMCS.

Kowalska, A., Bieniek, M., \& Manning, L. (2019) Food supplements' non-conformity in Europe - Poland: a case study, Trends in Food Science and Technology, 93, 262-270. doi: 10.1016/j.tifs.2019.09.022 
Kowalska, A., Soon, J.M., \& Manning, L. (2018). A study on adulteration in cereals and bakery products from Poland including a review of definitions. Food Control, 92, 348-356. doi: 10.1016/j.foodcont.2018.05.007

Kowalska, A., \& Kowalski, J. (2018). Administrative liability related to food fraud. A case of Poland. In: S. Kapounek \& V. Kočiš Krůtilová (Eds.), Enterprise and Competitive Environment. Proceedings of the $21^{\text {st }}$ Annual International Conference of Faculty of Business and Economics at Mendel University in Brno (pp. 339-350). Brno: Mendel University in Brno. Retrieved from http://ece.mendelu.cz/wcd/w-rekece/ece2018_fin.pdf (22.05.2019).

Lachenmeier, D.W. (2016). 21 - Advances in the Detection of the Adulteration of Alcoholic Beverages Including Unrecorded Alcohol. In: G. Downey (Ed.), Advances in food authenticity testing (pp. 565-584). Sawston: Woodhead Publishing. doi: 10.1016/B978-0-08-100220-9.00021-7

Lachenmeier, D.W., Neufeld, M., \& Rehm, J. (2021). The impact of unrecorded alcohol use on health: What do we know in 2020? Journal of Studies on Alcohol and Drugs, 82(1), 28-41. doi: 10.15288/jsad.2021.82.28

Laher, A.E., Goldstein, L.N., Wells, M.D., Dufourq, N., \& Moodley, P. (2013). Unwell after drinking homemade alcohol - A case of ethylene glycol poisoning. African Journal of Emergency Medicine, 3(2), 71-74. doi: 10.1016/j.afjem.2012.10.002

Maciejczak, M. (2017). Innovations in viticultural production in Poland under climate change conditions. Annals of the Polish Association of Agricultural and Agribusiness Economists, 19(2), 151-157. doi: 10.5604/01.3001.0010.1179

Manning, L., \& Kowalska, A. (2021). Illicit Alcohol: Public Health Risk of Methanol Poisoning and Policy Mitigation Strategies. Foods, 10(7), 1625. doi: 10.3390/ foods10071625

Manning, L., \& Soon, J.M. (2014). Developing systems to control food adulteration. Food Policy, 49(1), 23-32. doi: 10.1016/j.foodpol.2014.06.005

Moskalewicz, J., \& Sierosławski, J. (2005). Dostępność ekonomiczna napojów spirytusowych a szkody zdrowotne [Economic accessibility of alcohol and its harmful health consequences]. Alcoholism and Drug Addiction, 18(4), 41-50.

Moskalewicz, J., Razvodovsky, Y., \& Wieczorek, Ł. (2016). East-west disparities in alcohol-related harm. Alcoholism and Drug Addiction, 29(4), 209-222. doi: 10.1016/j.alkona.2016.11.003

Neufeld, M., Lachenmeier, D., Hausler, T., \& Rehm, J. (2016). Surrogate alcohol containing methanol, social deprivation and public health in Novosibirsk, Russia. International Journal of Drug Policy, 37, 107-110. doi: 10.1016/j.drugpo.2016.08.001

Newman, I. M., Qian, L., Tamrakar, N., \& Zhang, B-B. (2018). Chemical Composition and Safety of Unrecorded Grain Alcohol (Bai Jiu) Samples from Three Provinces 
in China. International Journal of Environmental Research and Public Health, 15(12), 2710. doi: 10.3390/ijerph15122710

Office of Competition and Consumer Protection (UOKiK). (2009-2019). The IH annual activity report. Retrieved from https://www.uokik.gov.pl/raporty_z_kontroli_inspekcji_handlowej.php (24.02.2020).

Olewnicki, D. (2018). Uprawa winorośli w Polsce w świetle danych statystycznych [Viticulture in Poland in the light of statistical data]. Annals of the Polish Association of Agricultural and Agribusiness Economists, 19(5), 139-145. doi: 10.5604/01.3001.0012.6698

Patterson, M.W., \& Hoalst-Pullen, N. (Eds.). (2014). The Geography of Beer: Regions, Environment, and Societies. Dordrecht: Springer.

Pietrzyck, K., Petersen, B., \& Jarzębowski, S. (2018). The role of quality management in the context of the Transatlantic Trade and Investment Partnership (TTIP): the case of the Polish agri-food sector. Problems of Agricultural Economics, 3(356), 94-110. doi: 10.30858/zer/94479

Power, A.C., Néill, C.N., Geoghegan, S., Currivan, S., Deasy, M., \& Cozzolino, D. (2020). A Brief History of Whiskey Adulteration and the Role of Spectroscopy Combined with Chemometrics in the Detection of Modern Whiskey Fraud. Beverages, 6, 49. doi: 10.3390/beverages6030049

Rezazade, F., Summers, J., \& Lai Teik, D.O. (2022). A holistic approach to food fraud vulnerability assessment. Food Control, 131, 108440. doi: 10.1016/j.foodcont.2021.108440

Rostrup, M., Edwards, J.K., Abukalish, M., Ezzabi, M., Some, D., Ritter, H., ... Lind, K. (2016). The methanol poisoning outbreaks in Libya 2013 and Kenya 2014. PloS one, 11(3), e0152676. doi: 10.1371/journal.pone.0152676

Shafi, H., Imran, M., Usman, H.F., Sarwar, M., \& Tahir, M.A. (2016). Eight fatalities due to drinking methanol-tainted alcohol in Pakistan: A case report. Egyptian Journal of Forensic Sciences, 6(4), 515-519. doi: 10.1016/j.ejfs.2016.06.004

Smith, R. (1982). Polish lessons on alcohol policy. British Medical Journal, 284(6309), 98-101.

Snowdon, C. (2012). Drinking in the shadow economy. IEA Discussion Paper no. 43. Retrieved from https://iea.org.uk/wp-content/uploads/2016/07/Drinking\%20 in\%20the\%20Shadow\%20Economy_0.pdf (25.08.2019).

Soares, N.F. (2020, August 4). Measuring food safety culture. Food Safety Magazine. Retrieved from https://www.food-safety.com/articles/6731-measuring-food-safety-culture (6.10.2021).

Soon, J.M., \& Manning, L. (2019). Developing anti-counterfeiting measures: the role of smart packaging. Food Research International, 123, 135-143. doi: 10.1016/j. foodres.2019.04.049 
Spink, J., \& Moyer, D.C. (2011). Backgrounder: defining the public health threat of food fraud. Retrieved from www.ncfpd.umn.edu (10.05.2019).

Statistics Poland. (2019). Concise Statistical Yearbook of Poland. Retrieved from https://stat. gov.pl/files/gfx/portalinformacyjny/pl/defaultaktualnosci/5515/1/21/1/maly_rocznik_statystyczny_polski_2019.pdf (18.03.2020).

Szajner, P. (2018). Ewolucja światowego rynku piwa [The Evolution of World Beer Market]. Problems of World Agriculture, 18(33), 4, 60-68. doi: 10.22630/PRS.2018.18.4.97 van Ruth, S.M., Luning, P.A., Silvis, I.C.J., Yang, Y., \& Huisman, W. (2018). Differences in fraud vulnerability in various food supply chains and their tiers. Food Control, 84, 375-381. doi: 10.1016/j.foodcont.2017.08.020

Wiśniewska, P., Śliwińska, M., Dymerski, T., Wardencki, W., \& Namieśnik, J. (2015). The Analysis of Vodka: A Review Paper. Food Analytical Methods, 8, 2000-2010. doi: 10.1007/s12161-015-0089-7

Wiśniewska, M.Z. (2016). System HARPC - nowy oręż w służbie bezpieczeństwa żywności [HARPC System - the New Weapon in the Service of Food Safety]. Problems of Quality, 9, 13-19. doi: 10.15199/47.2016.9.2

Wiśniewska, M.Z. (2018). Kultura bezpieczeństwa żywności. Istota i narzędzia pomiaru [Food safety culture. The essence of the concept and measurement instruments]. Warszawa: CeDeWu.

Wojtyra, B., \& Grudzień, Ł. (2017). The development of the beer industry in Poland during "craft beer revolution" (2011-2016). Studies of the Industrial Geography Commission of the Polish Geographical Society, 31(1), 52-67. doi: 10.24917/20801653.311.4

World Health Organization (WHO). (2014). Global Status Report on Alcohol and Health 2014. Retrieved from https://apps.who.int/iris/bitstream/handle/10665/112736/9789240692763_eng.pdf;jsessionid=1676573A8BCF311A97A 923A8BBAAAE06? sequence=1 (15.02.2020).

Yan, J., Erasmus, S.W., Toro, M.A., Huang, H., \& van Ruth, S.M. (2020). Food fraud: Assessing fraud vulnerability in the extra virgin olive oil supply chain. Food Control, 111, 107081. doi: 10.1016/j.foodcont.2019.107081

Yang, Y., Huisman, W., Hettinga, K.A., Liu, N., Heck, J., Schrijver, G. H., ... van Ruth, S.M. (2019). Fraud vulnerability in the Dutch milk supply chain: Assessments of farmers, processors and retailers. Food Control, 95, 308-317. doi: 10.1016/j. foodcont.2018.08.019

Yeomans, H. (2019). Regulating drinking through alcohol taxation and minimum unit pricing: A historical perspective on alcohol pricing interventions. Regulation \& Governance, 13(1), 3-17. doi: 10.1111/rego.12149 


\section{Summary}

Gaps in market governance create a vulnerability for adulteration to occur and the paper concludes with framing the challenges of addressing the sale of adulterated and mislabelled alcoholic beverages in Poland. The aim of the study was to review and critique the incidence of adulteration of alcoholic beverages in Poland, between 2009 and 2019, in order to provide recommendations for governance structures to reduce the likelihood of such offences occurring in the future. The methodological approach was to firstly review existing literature to position the Polish alcoholic beverage sector and consider food adulteration and then to analyse more specifically: (1) Agricultural and Food Quality Inspection (IJHARS) data on the prevalence of adulteration of alcoholic beverages in Poland; (2) Trade Inspection (IH) data on the prevalence of mislabelling of alcoholic beverages in Poland. The analysis of the IH data for the period 2009-2019 showed that alcoholic beverages in Poland were less commonly mislabelled than other food product categories. Focused analysis of IJHARS data between 2016-2019 for the beverages of concern $(n=56)$ revealed that most non-compliances were due to missing items in the list of ingredients, lower actual alcoholic strength of the product than the value declared, or a misnomer i.e. incorrect or incomplete name of the product. Since Poland is a significant producer and consumer of vodka and beer in Europe and throughout the world, formal food quality and safety management systems should be put in place for protecting the integrity of the products and positive food safety culture should be created, measured and systematically improved in the enterprises operating in alcoholic beverages industry.

KEYWORDS: food adulteration, mislabelling, alcoholic beverages market, beer, Poland

\section{Streszczenie}

Słabnąca kontrola na rynku napojów alkoholowych w Polsce sprawia, że rośnie podatność tych produktów na zafałszowania i nieprawidłowości w oznakowaniu. Celem artykułu było dokonanie krytycznego przeglądu przypadków zafałszowań napojów alkoholowych w Polsce z lat 2009-2019 oraz sformułowanie rekomendacji dla struktur zarządzania w obszarze przeciwdziałania niezgodnościom. Podejście metodologiczne obejmowało: (1) przegląd literatury dotyczącej fałszowania żywności oraz pozycji polskiej branży napojów alkoholowych w gospodarce; (2) analizę danych pochodzących z upublicznionych decyzji Inspekcji Jakości Handlowej Artykułów Rolno-Spożywczych (IJHARS) dotyczących zafałszowań żywności oraz wyników kontroli Departamentu Inspekcji Handlowej Urzędu Ochrony Konkurencji i Konsumentów (IH UOKiK) w zakresie oznakowania. Analiza danych IH z lat 2009-2019 dowiodła, że napoje alkoholowe są relatywnie rzadziej fałszowane w Polsce niż produkty żywnościowe z innych grup technologicznych. Szczegółowa analiza danych IJHARS z lat 2016-2019 dotyczących 56 zafałszowanych napojów alkoholowych wykazała, że wśród najczęściej stwierdzanych nieprawidłowości były: pominięcie w wykazie pewnych składników, które powinny się w nim znaleźć, zaniżona zawartość alkoholu etylowego w produkcie względem deklaracji na etykiecie, 
błędnie oznaczona nazwa produktu. Ze względu na mocną pozycję Polski na europejskim i światowym rynku wódki i piwa warto zwiększać skalę wdrożenia systemów zarządzania jakością i bezpieczeństwem żywności właściwych do walki, przeciwdziałania i łagodzenia skutków fałszowania tych produktów, aby chronić ich wiarygodność. Ogromne znaczenie ma tu zwłaszcza kształtowanie, pomiar i doskonalenie pozytywnej kultury bezpieczeństwa żywności w przedsiębiorstwach z branży alkoholowej.

SŁOWA KLUCzOWE: fałszowanie żywności, nieprawidłowe etykietowanie, rynek napojów alkoholowych, piwo, Polska.

\section{Noty o autorach}

Aleksandra Kowalska - Dr habil., Prof. UMCS, Department of Microeconomics and Applied Economics, Institute of Economics and Finance, Maria Curie-Skłodowska University. She is an expert the area of protecting integrity of food supply chain from fraud and adulteration. Her expertise is also in the area of food security, food policy and governance, and sustainable food systems; e-mail: aleksandra.kowalska@umcs.lublin.pl; ORCID: 0000-0003-3854-951X.

Louise Manning - Prof., School of Agriculture, Food and Environment, Royal Agricultural University, Cirencester, Gloucestershire, UK. She is an expert in the area of agri-food supply chain, food security and food integrity including food safety, food quality, food crime, policy and governance, social and corporate responsibility, resilience, risk assessment and mitigation strategies; e-mail: louise.manning@rau.ac.uk; ORCID: 0000-0002-9900-7303. 